\title{
ORIGINALES
}

\section{Comorbilidad psiquiátrica en jóvenes-adultos consumidores de cannabis}

\section{Psychiatric morbidity among young-adults cannabis users}

\author{
Aida M Cuenca-Royo, ; Marta TorRens ${ }^{* * * * * * *} ;$ Albert \\ SÁNCHEZ-NIUBÓ; ; JOSEP M SUELVES ${ }^{*+* t+}$; ANTÒNIA \\ DOMINGO-SALVANY,
}

* Drug Abuse Epidemiology Research Group. IMIM - Institut Hospital del Mar d'Investigacions Mèdiques.

** CIBER en Epidemiología y Salud Pública (CIBERESP).

${ }^{\star * *}$ IAPS - Parc de Salut Mar.

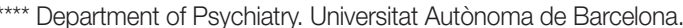

***** Direcció General de Salut Pública, Departament de Salut de la Generalitat de Catalunya.

Enviar correspondencia a:

Antònia Domingo-Salvany

Grupo de Investigación en Epidemiología de las Drogas de Abuso

IMIM-Hospital de Mar

Dr. Aiguader, 88

08003 Barcelona, Spain

Phone: 34-933160757

Fax: 34-933160797

adomingo@imim.es

\section{Resumen}

Este estudio transversal tiene como objetivo determinar la prevalencia vida de trastornos psiquiátricos (incluyendo los trastornos por uso de sustancias, -TUS y los otros trastornos no por uso de sustancias, -No-TUS) entre 289 jóvenes (18-30 años) consumidores regulares de cannabis durante el último año, reclutados fuera del entorno asistencial en Barcelona. Se administró la versión española de la Psychiatric Interview for Substance and Mental Disorders (PRISM). Sólo el 28\% de los participantes no presentó ningún trastorno psiquiátrico, y el 65\% tenía algún TUS, el más común relacionado con el cannabis (62\%). Casi el 27\% presentó trastornos no-TUS. Una edad de inicio más temprana en el consumo de alcohol se asoció con la presencia de algún TUS. Haber consumido un número mayor de "porros" en el último mes se asoció con la presencia de trastornos psiquiátricos (TUS y no-TUS). Mientras tres cuartas partes de los pacientes con trastornos no-TUS habian recibido algún tipo de tratamiento, sólo el 28\% de las personas con cualquier TUS habian recibido tratamiento. Dada la baja percepción de necesidad de tratamiento, se hacen necesarias estrategias de prevención y poder ofrecer terapias adaptadas y dirigidas a los consumidores jóvenes de cannabis.

\section{Abstract}

This cross-sectional study aims to determine lifetime prevalence of psychiatric disorders (including substance use disorders, -SUD and other non substance use disorders, -Non-SUD) among 289 young (1830 years) regular cannabis users, during the last year, in non-clinical settings in Barcelona. The Spanish version of the Psychiatric Interview for Substance and Mental Disorders (PRISM) was administered. Only 28\% of the participants did not present any psychiatric disorder; while $65 \%$ had some SUD, the most common related to cannabis use (62\%). Nearly $27 \%$ presented a non-SUD disorder. A younger age of initiation on alcohol use was associated with the presence of some SUD. Having consumed a greater number of "joints" in the last month was associated with the presence of both psychiatric disorders (SUD and non-SUD). While three quarters of subjects with non-SUD disorders had received some kind of treatment, only $28 \%$ of those with any SUD had received treatment. Given the low perception for need of treatment, there is a need for prevention strategies and to be able to offer therapies specifically tailored targeting young cannabis users.

Key Words: cannabis, psychiatric disorders, treatment, PRISM. 
$\mathrm{R}$ egular use of cannabis may be associated with a variety of health, emotional, behavioural, social and legal problems particularly in young and in severely mentaIly ill people (Winstock, Ford, \& Witton, 2010). Of the various mental conditions, the most studied are depression, anxiety and psychosis, the latter with more emphasis due to its clinical relevance (Arendt, Rosenberg, Foldager, Perto, \& MunkJorgensen, 2005; Caspi et al., 2005; de Irala, Ruiz, \& Martinez, 2005; Macleod, \& Hickman, 2010; Moore et al., 2007; Veen et al., 2004). An epidemiological study in the general population found that in subjects with cannabis dependence prevalences of mood and anxiety disorders in the last 12 months were 48\% and 44\%, respectively (Stinson, Ruan, Pickering, \& Grant, 2006). Also, when compared to the general population, cannabis consumers seeking treatment have a high proportion of other conditions such as psychosis and cognitive deficits (Arendt, Rosenberg, Foldager, Sher, \& Munk-Jorgensen, 2007; Lynskey, \& Hall, 2000; Solowij, Stephens, \& Roffman, 2002).

Although the prevalence of cannabis consumption is high, various studies show that only a small proportion of people abusing or dependent on cannabis seek treatment. According to the National Survey on Drug Use and Health (NSDUH) conducted by SAMHSA, 23.2 million people in the United States (9.4\%) aged over 11 years (National Survey on Drug Use and Health, 2008) needed treatment for substance use disorders in 2007. However, a large percentage (90\%) of those needing it did not receive any form of treatment. The same was found by the National Epidemiological Survey on Alcohol and Related Conditions (NESARC) study, in which only $9.8 \%$ of abusers and $34.7 \%$ of people with dependence received treatment (Stinson et al., 2006). Although Spain is one of the leading European Union countries in terms of cannabis consumption, the treatment demand indicator reports that under $12 \%$ of drug treatment admissions had cannabis as the main substance (Observatorio Europeo de las Drogas y Toxicomanías, 2009).

In Spain, research on psychiatric comorbidity among drug users, including cannabis, has mostly focused on clinical samples (Astals et al., 2009; Barea et al., 2010; Gonzalvo, Barral, GrauLópez, Esteve, \& Roncero, 2012; Nocon, Berge, Astals, MartinSantos, \& Torrens, 2007; Szerman et al., 2011). Therefore, young, regular cannabis users who are not in treatment constitute an interesting group of subjects in which to study associated psychiatric morbidity. Thus, the aim of the present study was to determine lifetime prevalence of psychiatric disorders among young subjects regularly consuming cannabis in the preceding year, recruited outside health care settings. This should allow analysing the proportion of subjects with psychiatric morbidity not having been treated for psychiatric conditions in another context.

\section{Method}

\section{Subjects}

This is a cross-sectional study of regular cannabis users. To be included in the study, subjects of either sex had to be aged
18 to 30 years, have consumed cannabis regularly (at least 12 times a year) in the last 12 months, and be residents of Barcelona or environs. Recruitment took place between July 2007 and March 2010, contacts being made in settings frequented by young people: universities and youth and leisure centres, by distributing leaflets which directed readers to a web site. Subjects were selected, based on data from questionnaires they completed on visiting a website (www.estudiardrogas.imim. es), in order to cover different levels of consumption previously defined: daily (over 25 joints per month), weekly (6-24 joints per month), and monthly (1-5 joints per month).

The study was approved by our institute's clinical research ethics committee.

Once they had signed an informed consent form in the research premises, participants had a baseline face-to-face interview to collect socio-demographic data, information about substances consumed ever in their life, patterns of use in the last month, and the Psychiatric Research Interview for Substance and Mental Disorders (PRISM) (Hasin et al., 1996). From this baseline interview, that could last 2 to 4 hours, some of them were selected to participate in other substance use related studies and were compensated with $30 €$.

Psychiatric conditions were diagnosed using the Spanish version of the PRISM (Torrens, Serrano, Astals, Perez-Dominguez, \& Martin-Santos, 2004). This is a semi structured questionnaire which uses DSM-IV criteria to diagnose Axis I disorders (mood disorders, anxiety disorders, psychotic disorders, eating disorders, substance-induced disorders) and axis II disorders (borderline personality disorder (BPD) and antisocial personality disorder (APD)), in subjects who are users of alcohol or other substances. In addition to the substance abuse and dependence diagnoses, the PRISM allows ascertainment of "pathological use" (substance use 4 or more days a week for 3 or more weeks; and/or 3 or more consecutive days of continuous substance use). The version used also included a section to diagnose attention-deficit/hyperactivity disorder (ADHD). Lifetime prevalences are reported. The interview was administered by an experienced psychologist who had received PRISM training.

We have defined a variable, "polysubstance use" for subjects diagnosed by the PRISM as having 3 or more SUD, excluding nicotine. Note also that we constructed the continuous variable "joints/ month", created by multiplying the number of joints consumed per day by the number of days consumed out of the last 30 days.

\section{Data analysis}

We considered the following dependent variables: 1) presence of "non-SUD axis I disorder", taking into account the following disorders: mood, anxiety, psychotic, eating and/or ADHD and 2) "presence of psychiatric pathology" which discriminates between absence of any psychiatric disorder, presence of only SUD, and presence of non-SUD (axis I and axis II) (subjects of the latter category could also present SUD).

Differences between qualitative variables were assessed using chi-square $\left(\chi^{2}\right)$ and Fisher's exact test; for quantitative variables we performed analysis of variance (ANOVA). 
Logistic regression models (binomial and multinomial) were used to study the influence of independent variables (sociodemographic, drug use patterns, psychological-psychiatric treatment for drugs/alcohol and if necessary the presence of other psychiatric conditions) on the dependent variables. The dependent variable for binomial analysis was non-SUD axis I disorder; for the multinomial analysis it was presence of psychiatric pathology (only SUD or non-SUD). In both analyses, absence of a disorder was taken as the reference. Logistic regression models were built using variables which yielded a p-value $<0.20$ in the univariate analysis (relevant variables). Variables which, once introduced into the model, were found not to be significant were withdrawn one by one. When variables correlated with others (i.e.: number of SUD and polysubstance) only one was introduced into the model. Age and sex were always included, regardless of their statistical significance. Goodness of fit of logistic regression models was assessed using the Hosmer-Lemeshow test.

P-values $<0.05$ were considered statistically significant; confidence intervals are 95\%. All analyses were conducted using the SPSS statistical package (version 12).

\section{Results}

A total of 289 subjects were studied, of whom $67.1 \%$ were men. The average age was 21.5 (SD 2.7) years. The majority of subjects had completed secondary education (70.9\%); the majority lived at home with their parents (61.6\%); 99\% were single. Nearly $7 \%$ had been arrested for at least one night. Women had higher educational levels $(p=0.01)$ and more lived with a partner $(p=0.01)$. (Table 1$)$

The average age of onset of cannabis use was 15 (SD 1.8) years, while for alcohol were 14.5 years in men and 14 in women. Although differences were not significant, for most substances the ages of onset were lower in women. (Table 1)

Half the subjects (49.8\%) consumed cannabis daily, 29.7\% weekly, and 20.4\% monthly. Overall, 30.3\% consumed between 3 and 4 joints per day of use, on average 75 per month. The majority had been consuming for between 5 and 7 years. Men consumed more often than women $(p=0.02)$, however no sex differences were found for quantity or duration of consumption. (Table 1)

\section{Substance use disorders}

Lifetime cannabis use disorder was observed in $62 \%$ of subjects (abuse, 25.3\% and dependence, 35.3\%), alcohol related SUD in $24.9 \%$ of subjects, and cocaine in $9 \%$. Frequencies were lower for other substances. The mean number of SUD diagnoses per individual was 1.03 (SD 1.02) and polisubstance use (3 or more SUD) was observed in $7.3 \%$ of subjects. No statistically significant differences for SUD by sex were observed; only few substance abuse (alcohol) or dependence (cannabis and hallucinogens) were related to sex. (Table 2)
Pathological use of cannabis was observed in $92 \%$ of men and $85 \%$ of women; for people who had tried alcohol ever $(n=272)$, the corresponding figures were $42 \%$ and $48 \%$, respectively, and for cocaine $24 \%$ and $32 \%$. The average age at onset of pathological cannabis use was 16.7 (SD 2) years in men and 16.9 (SD 1.8) in women (very similar to those of alcohol). For cocaine the average age of pathological use was 19.5 (SD 3.9) years in men $(n=19)$ and 18 (SD 2) in women ( $n=12)$ (very similar to that of stimulants).

\section{Psychiatric disorders}

As a summary, $28 \%$ of subjects did not present any DSMIV diagnosis; $47.1 \%$ only presented a substance use disorder; $18 \%$ presented psychiatric comorbidity involving some Axis I and/or Axis II disorder concomitant with some SUD; 6.5\% were diagnosed with some Axis I and/or Axis II non-SUD but no SUD. No significant differences were found by sex. (Table 2)

As seen in table 2, 62 subjects (21.5\%) presented some Axis I non-SUD, $13.5 \%$ mood disorder, $3.5 \%$ an anxiety disorder, $2.4 \%$ an eating disorder (ED), 1.7\% were diagnosed with ADHD and 1.4\% psychotic disorder. Overall, 5\% were substance-induced disorders, mainly mood disorders. Although a higher proportion of women (14.7\%) had a diagnosis of major depression, significant differences by sex, among Axis I disorders were only observed for ED.

Axis II disorders were diagnosed in 5.9\% of subjects, 3.8\% being antisocial and 3.1\% borderline personality disorders. Gender differences were not significant.

A total of 81 subjects did not have any disorder; they had a higher educational level, none of them had been arrested, and in relation to patterns of use they had been using cannabis for a shorter time, consumed smaller amounts and had lower frequencies of use than those who were diagnosed with some psychiatric disorder.

\section{Treatment experience}

Nearly $40 \%$ of subjects reported having undergone psychological, psychiatric or drug abuse related treatment at some time in their lives. Of these, $94 \%$ were for psychological and/or psychiatric problems, 3\% for problems related with alcohol or drug consumption, and $4 \%$ for both. Seventy-five percent of those who presented some non-SUD received some form of treatment, while only $28 \%$ of those presenting only SUD received treatment. No differences were observed by sex.

\section{Variables related with psychiatric disorders}

Apart from psychological and/or psychiatric treatment, age, living arrangements, employment status, prison history, duration of consumption, polysubstance use, Axis II pathology, and number of joints per month were associated to "presence of Axis I non-SUD". In the multivariate analysis (not including psychological or psychiatric treatment) polysubstance use $(\mathrm{OR}=3.4, \mathrm{Cl}=1.4-8.6)$ and age $(\mathrm{OR}=1.1, \mathrm{Cl}=1.03-1.3)$ were both independently associated with presence of Axis I nonSUD. (Table 3) 
Table 1. Socio-demographic characteristics and patterns of use of young cannabis users

\begin{tabular}{|c|c|c|c|c|c|c|c|}
\hline & \multicolumn{2}{|c|}{$\begin{array}{l}\text { Total } \\
289\end{array}$} & \multicolumn{2}{|c|}{$\begin{array}{c}\text { Men } \\
194(67.1 \%)\end{array}$} & \multicolumn{2}{|c|}{$\begin{array}{c}\text { Women } \\
95(32.9 \%)\end{array}$} & \multirow[t]{2}{*}{$\begin{array}{c}\mathrm{p} \\
\text { value }\end{array}$} \\
\hline & $n$ & $\%$ & $n$ & $\%$ & $\mathrm{n}$ & $\%$ & \\
\hline \multicolumn{8}{|l|}{ Educational Level } \\
\hline School certificate & 13 & 4.5 & 10 & 5.2 & 3 & 3.2 & $0.01^{*}$ \\
\hline Graduate school & 26 & 9.0 & 24 & 12.4 & 2 & 2.1 & \\
\hline High school & 205 & 70.9 & 135 & 69.6 & 70 & 73.7 & \\
\hline Bachelor degree & 45 & 15.6 & 25 & 12.9 & 20 & 21.1 & \\
\hline \multicolumn{8}{|l|}{ Employment status } \\
\hline Employed & 76 & 26.3 & 44 & 22.7 & 32 & 33.7 & 0.12 \\
\hline Unemployed & 62 & 21.5 & 42 & 21.6 & 20 & 21.1 & \\
\hline Student & 151 & 52.2 & 108 & 55.7 & 43 & 45.3 & \\
\hline \multicolumn{8}{|l|}{ Living arrangements } \\
\hline Parents & 178 & 61.6 & 130 & 67.0 & 48 & 50.5 & $0.01^{*}$ \\
\hline Couple & 22 & 7.6 & 9 & 4.6 & 13 & 13.7 & \\
\hline Friends & 56 & 19.4 & 35 & 18.0 & 21 & 22.1 & \\
\hline Other & 33 & 11.4 & 20 & 10.3 & 13 & 13.7 & \\
\hline \multicolumn{8}{|l|}{ Criminal History } \\
\hline Arrested at least one night & 20 & 6.9 & 16 & 8.2 & 4 & 4.2 & 0.32 \\
\hline \multicolumn{8}{|l|}{ SUBSTANCE USE } \\
\hline \multicolumn{8}{|l|}{ Length of cannabis use } \\
\hline $1-4$ years & 92 & 31.8 & 61 & 31.4 & 31 & 32.6 & 0.12 \\
\hline $5-7$ years & 118 & 40.8 & 73 & 37.6 & 45 & 47.4 & \\
\hline$>7$ years & 79 & 27.3 & 60 & 30.9 & 19 & 20.0 & \\
\hline \multicolumn{8}{|l|}{ Frequency of cannabis use } \\
\hline Daily (>25 day/month) & 134 & 49.8 & 96 & 53.6 & 38 & 42.2 & $0.02^{*}$ \\
\hline Weekly (6-24 day/month) & 80 & 29.7 & 55 & 30.7 & 25 & 27.8 & \\
\hline Monthly (<6 day/month) & 55 & 20.4 & 28 & 15.6 & 27 & 30 & \\
\hline \multicolumn{8}{|l|}{ Quantity of cannabis use } \\
\hline 1 joint/day & 64 & 24.2 & 37 & 21.0 & 27 & 30.7 & 0.13 \\
\hline 2 joint/day & 60 & 22.7 & 37 & 21.0 & 23 & 26.1 & \\
\hline 3-4 joint/day & 80 & 30.3 & 60 & 34.1 & 20 & 22.7 & \\
\hline$>=5$ joint/day & 60 & 22.7 & 42 & 23.9 & 18 & 20.5 & \\
\hline $\begin{array}{l}\text { Polysubstance } 3 \text { SUD }^{\text {a }} \\
\text { or more }\end{array}$ & 21 & 7.3 & 14 & 7.2 & 7 & 7.4 & 1 \\
\hline \multirow[t]{2}{*}{$\begin{array}{l}\text { Psychiatric/Psychologi- } \\
\text { cal and/or drug/alcohol } \\
\text { treatment }\end{array}$} & 111 & 39.4 & 71 & 38 & 40 & 42.1 & 0.5 \\
\hline & mean & $s d^{b}$ & mean & sd & mean & sd & \\
\hline Age & 21.5 & 2.73 & 21.6 & 2.9 & 21.2 & 2.45 & 0.2 \\
\hline Age at first Cannabis use & 15.1 & 1.8 & 15.1 & 1.8 & 15.2 & 1.9 & 0.8 \\
\hline Joints last 30 days & 75 & 85 & 79.4 & 79.7 & 66.02 & 94.7 & 0.23 \\
\hline \multicolumn{8}{|l|}{$\begin{array}{l}\text { Age at first use of other } \\
\text { substances }\end{array}$} \\
\hline Alcohol & 14.4 & 1.9 & 14.5 & 2.1 & 14.01 & 1.5 & $0.04^{*}$ \\
\hline Benzodiazepines & 17.7 & 4.8 & 18.5 & 5.7 & 16 & 2.8 & 0.6 \\
\hline Cocaine & 18.1 & 2.4 & 18.5 & 2.5 & 17.2 & 2.1 & $0.01^{*}$ \\
\hline Heroin & 19 & 0.8 & 19 & 1 & 19 & 0 & 1 \\
\hline Stimulants & 18 & 2.3 & 18.2 & 2.5 & 17.4 & 1.8 & 0.21 \\
\hline \multicolumn{8}{|l|}{$\begin{array}{l}{ }^{*} p<0.05 \\
\text { a SUD: Subs }\end{array}$} \\
\hline
\end{tabular}

Table 2. Lifetime prevalence of psychiatric diagnoses by sex

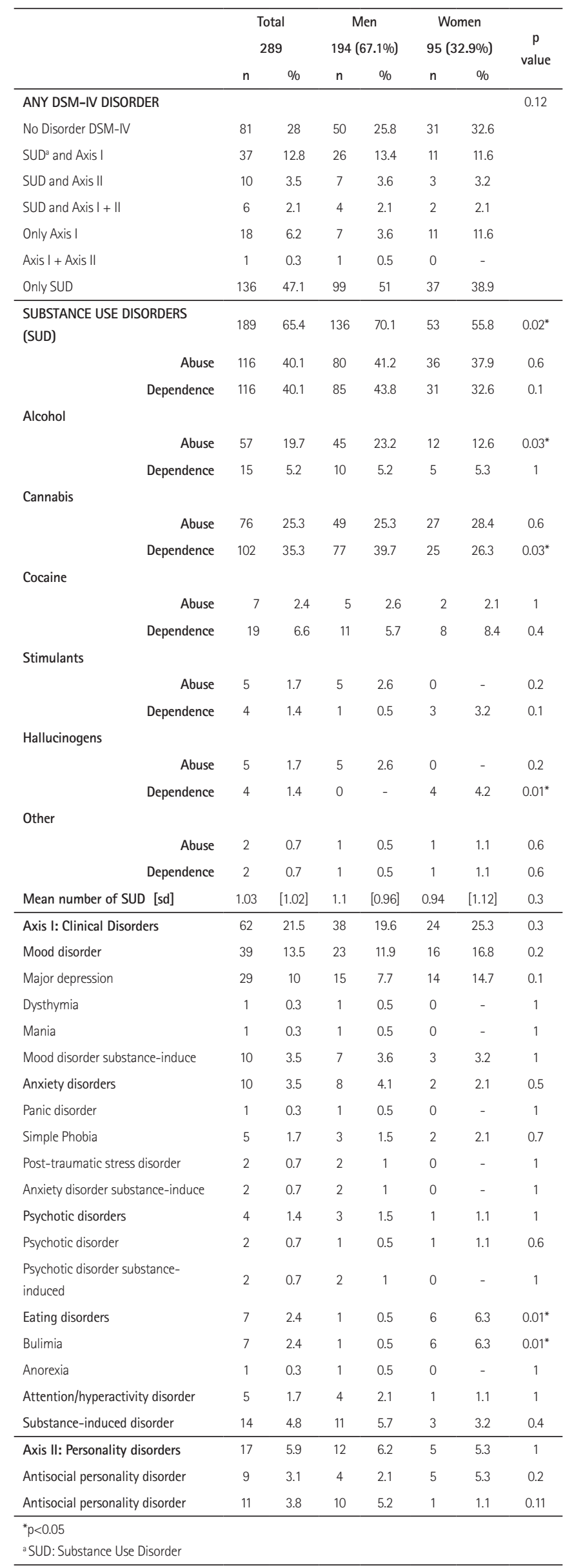


Table 3. Socio-demographic variables, patterns of use and Axis II disorders in relation to the non-SUDa Axis I disorders, in young cannabis users. Logistic regression analysis

\begin{tabular}{|c|c|c|c|c|c|c|c|c|}
\hline \multirow[b]{2}{*}{ Men } & \multicolumn{2}{|c|}{$\begin{array}{l}\text { Axis I Yes } \\
n=62(\%)\end{array}$} & \multicolumn{2}{|c|}{$\begin{array}{l}\text { Axis I No } \\
n=227(\%)\end{array}$} & \multicolumn{2}{|c|}{$\mathrm{OR}^{\mathrm{b}}\left(95 \% \mathrm{Cl}^{\mathrm{c}}\right)$} & \multicolumn{2}{|c|}{$\begin{array}{l}\text { Adjusted OR } \\
(95 \% \mathrm{Cl})\end{array}$} \\
\hline & 38 & 61.3 & 156 & 68.7 & 1.00 & & & \\
\hline Women & 24 & 38.7 & 71 & 31.3 & 1.39 & $(0.78,2.5)$ & 1.5 & $(0.8,2.8)$ \\
\hline \multicolumn{9}{|l|}{ Living arrangements } \\
\hline Parents & 33 & 53.2 & 145 & 63.9 & 1,00 & & & \\
\hline Couple/Friends & 25 & 40.3 & 53 & 23.3 & 2.1 & $(1.13,3.81)$ & & \\
\hline Other & 4 & 6.5 & 29 & 12.8 & 0.61 & $(0.2,1.84)$ & & \\
\hline Employment status & & & & & & * & & \\
\hline Employed & 23 & 37.1 & 53 & 23.3 & 1,00 & & & \\
\hline Unemployed & 15 & 24.2 & 47 & 20.7 & 0.74 & $(0.34,1.57)$ & & \\
\hline Student & 24 & 38.7 & 127 & 55.9 & 0.44 & $(0.23,0.84)$ & & \\
\hline \multicolumn{9}{|l|}{ Educational Level } \\
\hline Graduate school & 8 & 12.9 & 31 & 13.7 & 1.00 & & & \\
\hline$>$ Graduate school & 54 & 87.1 & 196 & 86.3 & 1.1 & $(0.5,2.46)$ & & \\
\hline Criminal History ${ }^{d}$ & 8 & 12.9 & 12 & 5.3 & 2.65 & $(1.03,6.82)^{*}$ & & \\
\hline \multicolumn{9}{|c|}{ Frequency of cannabis use ${ }^{e}(n=269)$} \\
\hline Daily (>25 day/month) & 27 & 47.4 & 107 & 50.5 & 1.01 & $(0.5,2.21)$ & & \\
\hline Weekly (6-24 day/month) & 19 & 33.3 & 61 & 28.8 & 1.25 & $(0.54,2.88)$ & & \\
\hline Monthly (<6 day/month) & 11 & 19.3 & 44 & 20.8 & 1.00 & & & \\
\hline \multicolumn{9}{|l|}{ Quantity of cannabis use $(n=264)$} \\
\hline 1 joint/day & 20 & 35.1 & 44 & 21.3 & 1.00 & & & \\
\hline 2 joint/day & 13 & 22.8 & 47 & 22.7 & 0.61 & $(0.27,1.37)$ & & \\
\hline 3-4 joint/day & 13 & 22.8 & 67 & 32.4 & 0.43 & $(0.19,0.95)$ & & \\
\hline$>=5$ joint $/$ day & 11 & 19.3 & 49 & 23.7 & 0.5 & $(0.21,1.15)$ & & \\
\hline \multicolumn{9}{|l|}{ Length of cannabis use ${ }^{\mathrm{e}}(\mathrm{n}=289)$} \\
\hline $1-4$ years & 19 & 30.6 & 73 & 32.2 & 1.00 & & & \\
\hline $5-7$ years & 19 & 30.6 & 99 & 43.6 & 0.74 & $(0.37,1.5)$ & & \\
\hline$>7$ years & 24 & 38.7 & 55 & 24.2 & 1.7 & $(0.84,3.4)$ & & \\
\hline Any SUD & 43 & 69.4 & 146 & 64.3 & 1.3 & $(0.69,2.3)$ & & \\
\hline Polysubstance 3 SUD or more ${ }^{f}$ & 10 & 16.1 & 11 & 4.8 & 3.8 & $(1.5,9.4)^{*}$ & 3.4 & $(1.4,8.6)$ \\
\hline Axis II & 7 & 41.2 & 55 & 20.2 & 2.76 & $(1.01,7.6)^{*}$ & & \\
\hline Antisocial personality disorder & 4 & 6.5 & 5 & 2.2 & 3.1 & $(0.8,11.8)$ & & \\
\hline \multirow[t]{2}{*}{ Antisocial personality disorder } & 5 & 8.1 & 6 & 2.6 & 3.23 & $(0.95,10.96)$ & & \\
\hline & mean & $\mathrm{sd}^{+}$ & mean & sd & & & & \\
\hline Age & 22.3 & 2.9 & 21.3 & 2.7 & 1.1 & $(1.04,1.3)^{*}$ & 1.1 & $(1.03,1.3)$ \\
\hline Joints last 30 days & 87.1 & 129.6 & 71.7 & 68.12 & 1.002 & $(0.99,1.01)$ & & \\
\hline \multicolumn{9}{|l|}{ Age at first use } \\
\hline Cannabis $(n=275)$ & 15.45 & 2.44 & 15 & 1.6 & 1.14 & $(0.98,1.32)$ & & \\
\hline Alcohol $(n=272)$ & 14.29 & 2.15 & 14.36 & 1.9 & 0.98 & $(0.85,1.14)$ & & \\
\hline Cocaine $(n=115)$ & 18.52 & 2.64 & 17.96 & 2.33 & 1.1 & $(0.93,1.3)$ & & \\
\hline Benzodiazepines $(n=6)$ & 16 & 2 & 19.33 & 6.7 & 0.8 & $(0.5,1.4)$ & & \\
\hline Stimulants $(n=4)$ & 19.1 & 2.73 & 17.6 & 2.1 & 1.31 & $(1.04,1.65)^{*}$ & & \\
\hline Mean Number of SUD & 1.35 & 1.31 & 0.94 & 0.91 & 1.45 & $(1.12,1.9)^{*}$ & & \\
\hline
\end{tabular}


Table 4. Distribution of significant variables and adjusted $O R s^{a}$ for the presence of Axis I and/or II psychiatric disorders and only SUD ${ }^{\mathrm{b}}$.

\begin{tabular}{|c|c|c|c|c|c|c|c|c|c|c|}
\hline & & & & & & & \multicolumn{4}{|c|}{ Multinomial Logistic Regression c } \\
\hline & \multicolumn{2}{|c|}{$\begin{array}{c}\text { No } \mathrm{Dx}^{\mathrm{d}} \\
\mathrm{n}=81(28 \%)\end{array}$} & \multicolumn{2}{|c|}{$\begin{array}{c}\text { Only SUD } \\
n=136(47 \%)\end{array}$} & \multicolumn{2}{|c|}{$\begin{array}{l}\text { Axis I and/or II } \\
n=72(25 \%)\end{array}$} & \multicolumn{2}{|c|}{ Only SUD adjusted OR } & \multicolumn{2}{|c|}{$\begin{array}{c}\text { Axis I and/or II adjusted } \\
\text { OR }\end{array}$} \\
\hline & $\mathrm{n}$ & $\%$ & $\mathrm{n}$ & $\%$ & $\mathrm{n}$ & $\%$ & OR & $\left(95 \% \mathrm{Cl}^{\mathrm{e}}\right)$ & OR & $(95 \% \mathrm{Cl})$ \\
\hline Men & 50 & 61.7 & 99 & 72.8 & 45 & 62.5 & 1.00 & & 1.00 & \\
\hline Women & 31 & 38.3 & 37 & 27.2 & 27 & 32.9 & 0.7 & $(0.3,1.3)$ & 1.2 & $(0.5,2.7)$ \\
\hline Treatment ${ }^{f}$ & 19 & 25.3 & 38 & 28.1 & 54 & 75 & 1 & $(0.5,2.2)$ & 10.9 & $(4.5,26.3)$ \\
\hline \multicolumn{11}{|c|}{ Length of cannabis use } \\
\hline $1-4$ years & 29 & 35.8 & 43 & 31.6 & 20 & 27.8 & 1.00 & & 1.00 & \\
\hline 5-7 years & 43 & 53.1 & 51 & 37.5 & 24 & 33.3 & 0.8 & $(0.4,1.9)$ & 1.06 & $(0.4,3)$ \\
\hline \multirow[t]{2}{*}{$>7$ years } & 9 & 11.1 & 42 & 30.9 & 28 & 38.9 & 7.3 & $(1.7,31.5)$ & 10.8 & $(2.0,58.6)$ \\
\hline & mean & ${s d^{g}}^{9}$ & mean & sd & mean & sd & & & & \\
\hline Age & 21.36 & 2.7 & 21.22 & 2.7 & 22.11 & 2.9 & 0.8 & $(0.6,0.9)$ & 0.9 & $(0.7,1.1)$ \\
\hline Joints last 30 days & 43.7 & 50.8 & 82.2 & 66.14 & 92.5 & 127.9 & 1.01 & $(1.004,1.02)$ & 1.01 & $(1.004,1.02)$ \\
\hline
\end{tabular}

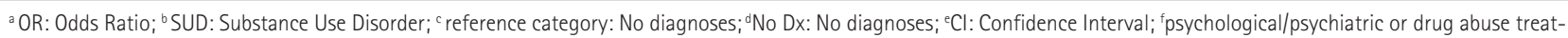
ment; ${ }^{9}$ sd: standard deviation.

In the multinomial logistic regression analysis of the dependent variable "presence of psychiatric pathology" with three categories (no disorder, only SUD, any non-SUD with or without SUD) the relevant variables included were: living arrangements, employment status, educational level, some psychiatric/psychological and/or drug/alcohol treatment, duration of consumption, number of joints per month and age of initiation of alcohol consumption. In Table 4 we only include those variables which were statistically significant, which for the category non-SUD were: some psychiatric/psychological treatment $(\mathrm{OR}=10, \mathrm{Cl}=4.4,25.4)$, duration of consumption $(\mathrm{OR}=9.9, \mathrm{Cl}=1.8-53.3)$ and number of joints per month $(\mathrm{OR}=$ $1.01, \mathrm{Cl}=1.003-1.02)$. For the category 'only SUD' they were: duration of consumption $(\mathrm{OR}=6.5, \mathrm{Cl}=1.5-28.1)$ and number of joints per month $(\mathrm{OR}=1.01, \mathrm{Cl}=1.003-1.02)$. (Table 4$)$

\section{Discussion}

In a non-clinical sample of regular cannabis users aged 18 to 30 years, $72 \%$ had a psychiatric disorder. Nearly two thirds of the total sample had a SUD, while a quarter presented a non-SUD, leading to $18 \%$ being comorbid with SUD. A younger age of alcohol onset was associated with the presence of at least one SUD. Having consumed more joints in the last month was associated with both the presence of non-SUD and SUD. While three quarters of subjects with non-SUD had received some kind of treatment, less than $30 \%$ of those with any SUD had received treatment.

We consider it important to highlight this last finding. It is reassuring that three quarters of subjects presenting some non-SUD had sought treatment at some time in their life. This proportion is higher than that observed for subjects seeking treatment for Axis I disorders in the last 12 months in a household representative sample of the Spanish population aged
18 years and over (35\%)(ESEMeD-Spain project)(Codony et al., 2007). However, only $28 \%$ of those subjects with any SUD had received treatment and the only variable associated with any psychiatric treatment (whether drug related or otherwise) was the presence of non-SUD, both Axis I and Axis II. In fact, some subjects only with SUD even sought psychiatric treatment not specific for drug use. This might not be specific of Spanish programs as a similar figure was observed in the NESARC study for cannabis use disorders (35\% had received treatment) (Stinson et al., 2006) and may be related to the widespread perception that cannabis is a relatively innocuous drug and the resistance to participate in treatment programs not employing cannabis-specific therapies (Weiner, Sussman, McCuller, \& Lichtman, 1999; Delegación del Gobierno para el Plan Nacional sobre Drogas y Ministerio de Sanidad y Consumo, 2006). To overcome this problem, some countries such as France have implemented specific treatment settings for cannabis users (Observatorio Europeo de las Drogas y las Toxicomanías, 2011).

SUD prevalence was very high among these young cannabis users, over a quarter of subjects were diagnosed with 2 or more SUD. However, in previous studies among young heroin and/or cocaine users recruited on the street, assessed with the same instrument, a higher prevalence of polydrug use was observed (Rodriguez-Llera et al., 2006; Herrero, Domingo-Salvany, Torrens, Brugal, \& and the ITINERE Investigators., 2008). Although non-SUD disorders were also lower among cannabis users than in these two cohorts, mood disorders (MD) were also the most prevalent Axis I disorders (13.5\%). This prevalence is similar to that observed for the subgroup of cannabis users in the ENTE study (Martin-Santos et al., 2009) which also employed the same psychiatric diagnostic interview for the comparison of ecstasy users to two control groups (cannabis users and healthy controls) and where no MD disorder was detected in the healthy group. Our prevalence of MD is slightly higher than the figure of $9.4 \%$ found in the ESEMeDSpain sample of a similar age, though still within its confiden- 
ce interval (Haro et al., 2008). Given that MD are the most common disorders, the present study lends support to previous reports suggesting that heavy use of cannabis can increase depressive symptoms in some users (Degenhardt, Hall, \& Lynskey, 2003), even though one cannot discount the hypothesis that the association may also be due to social, family and contextual factors, aspects which increase both the risks of heavy cannabis use (more joints in this study) and the appearance of depressive symptoms (Degenhardt et al., 2003).

In our case, an early age of initiation of alcohol consumption was related with the presence of SUD. This has also been found in other studies which have observed that exposure to a given substance during adolescence, such as alcohol, tobacco or cannabis, among others, increased the risk of problems (SUD) with that substance later on (Palmer et al., 2009), or predisposed to use of other substances: the so-called gateway phenomenon (Degenhardt et al., 2010).

Heavier cannabis use was associated not only to the presence of substance use disorders, but also to non-SUD, in agreement with earlier findings where it was observed that subjects with heavier cannabis use were more likely to have had alcohol dependence or to have had a major depressive episode in the last year (Grant, \& Pickering, 1998). Also, in a sample of subjects entering psychiatric treatment, psychiatric comorbidity was associated with heavy cannabis use (Grella, Hser, Joshi, \& Rounds-Bryant, 2001). Of note, in our sample, subjects without any psychiatric disorder declared lighter cannabis use.

Psychiatric disorders were diagnosed using the PRISM questionnaire, widely accepted for its reliability and validity in assessing substance-consuming subjects (Hasin et al., 1996; Torrens et al., 2004) so that we consider the present study to have good internal validity. However, the PRISM only considers two Axis II diagnostic categories (antisocial and borderline disorders). Although this fact may have led to an underestimation of other personality disorder diagnoses in the study population, it may not be relevant as USA national survey findings indicate a very high level of association between personality disorders (Grant, Stinson, Dawson, Chou, \& Ruan, 2005). Furthermore, these two disorders are the more frequent personality disorders described in substance abusing populations (Rounsaville et al., 1998); also in Spanish studies (Barea et al., 2010; Casares-Lopez et al., 2011; Roncero et al., 2011) and specifically, antisocial personality disorder in adults and conduct disorder in adolescents were the disorders that showed a stronger association with cannabis dependence (Agosti, Nunes, \& Levin, 2002). On the other hand, consistently with other studies, we observed that the fact of presenting a personality disorder appeared to be associated with lower educational level (Lee et al., 2009).

The prevalence of anxiety disorders found in our sample $(3.5 \%)$ is much lower than that reported by other studies, whether involving substance users in treatment (6.8\%) (Arendt \& Munk-Jorgensen, 2004), recruited in the street (16.8\% and $12.9 \%$ for heroin and cocaine, respectively) ( Herrero et al., 2008; Rodriguez-Llera et al., 2006), or population surveys, both in Spain (ESEMeD-Spain) (Haro et al., 2008) where the prevalence was $12 \%$ and in the USA (NESARC) (Stinson et al.,
2006), where the prevalence of anxiety disorder among those subjects with a disorder related to cannabis use was $31 \%$.

Although some studies that have analysed psychiatric comorbidity among cannabis users had larger samples, especially those provided by general population surveys (Agosti et al., 2002; Stinson et al., 2006) and by treatment registries (Arendt, \& Munk-Jorgensen, 2004; Arendt et al., 2005; Arendt et al., 2007; Guillem, Pelissolo, Vorspan, Bouchez-Arbabzadeh, \& Lépine, 2009; Tims et al., 2002), we must take into account that the present sample, composed of young regular cannabis consumers, is rather a particular sample that could be located between consumers in the general population samples and consumers in treatment settings. The fact that our study analyses young cannabis users outside the health care system, offers another perspective on psychiatric morbidity among young cannabis users. We also want to emphasize that this is a hard-to-reach population that we tried to access through widely distributed leaflets and advertisements allowing access to potentially hidden subjects. However, this recruitment is likely to be selective since the process requires more action from the participants after having access to a computer and internet connection (Miller, \& Sonderlund, 2010). And, although we cannot claim our subjects to be a representative sample of the population, patterns of cannabis use as well as ages of initiation among both males and females were similar to those found in Spanish general population surveys (Observatorio Español de Drogas, 2009). Nevertheless, we cannot dismiss the possibility that the form of recruitment and voluntary participation could influence retrieval of subjects with psychotic disorders, thus influencing its prevalence. A recent study in a population of university students seen in general practice found that more frequent cannabis use was associated to greater psychotic symptoms. Unfortunately, in our study only a definite diagnosis of psychosis was considered, maybe "losing" sub threshold diagnosis (Skinner, Conlon, Gibbons, \& McDonald, 2011).

Another limitation which must be taken into account is that, given that the data was self-reported, the collection of data for certain variables may be influenced by the existence of recall bias (e.g. estimation of the quantity and frequency of consumption). Also, as this is a cross-sectional study, caution is needed when evaluating the direction of observed associations.

The high prevalence of mental disorders, particularly substance use related disorders, found in this otherwise "normalized" sample of cannabis consumers, together with the vulnerability of these young people to substance abuse and dependence, and the extent of cannabis use among youth, points to the need for continued work to establish effective prevention strategies targeting adolescents and young adults. Furthermore, the results of the present study show that it is important for young cannabis users to identify problems that cannabis use entails, and to perceive the need for its treatment. Given the important health, cognitive and social consequences that cannabis use involves, adequate strategies to detect problematic use and to offer therapies specifically tailored to cannabis use are of the utmost importance. 


\section{Acknowledgements}

We are grateful for the support provided by the ETS (PI06/90491), FIS (PI070960), FIS-Redes de investigación cooperativa RD12/0028/0009 and 0018; and AGAUR 2009 SGR 718. Albert Sánchez-Niubó is supported by ISCIII grant CA08/00214. We also are grateful to Joan Rodriguez for recruitment and to Dave Macfarlane for English revision.

\section{Conflicts of interest}

The authors declare that they have no conflicts of interest concerning this article.

\section{References}

Agosti, V., Nunes, E., \& Levin, F. (2002). Rates of psychiatric comorbidity among U.S. residents with lifetime cannabis dependence. American Journal of Drug and Alcohol Abuse, 28, 643-652.

Arendt, M. \& Munk-Jorgensen, P. (2004). Heavy cannabis users seeking treatment- prevalence of psychiatric disorders. Social Psychiatry and Psychiatric Epidemiology, 39, 97-105.

Arendt, M., Rosenberg, R., Foldager, L., Perto, G., \& Munk-Jorgensen, P. (2005). Cannabis-induced psychosis and subsequent schizophreniaspectrum disorders: follow-up study of 535 incident cases. British Journal of Psychiatry, 187, 510-515.

Arendt, M., Rosenberg, R., Foldager, L., Perto, G., \& Munk-Jorgensen, P. (2007). Psychopathology among cannabis-dependent treatment seekers and association with later substance abuse treatment. Journal of Substance Abuse Treatment, 32, 113-119.

Arendt, M., Rosenberg, R., Foldager, L., Sher, L., \& Munk-Jorgensen, P. (2007). Withdrawal symptoms do not predict relapse among subjects treated for cannabis dependence. American Journal on Addictions, 16, 461-467.

Astals, M., Diaz, L., Domingo-Salvany, A., Martín-Santos, R., Bulbena, A., \& Torrens, M. (2009). Impact of Co-Occurring Psychiatric Disorders on Retention in a Methadone Maintenance Program: An 18-Month Follow-Up Study. International Journal of Environmental Research and Public Health, 6, 2822-2832.

Barea, J., Benito, A., Mateu, C., Martin, E., Lopez, N., \& Haro, G. (2010). Research on etiological aspects of dual pathology. Adicciones, 22, 15-24.

Casares-Lopez, M. J., Gonzalez-Menendez, A., Bobes-Bascaran, M. T., Secades, R., Martinez-Cordero, A., \& Bobes, J. (2011). Need for the assessment of dual diagnosis in prisons. Adicciones, 23, 37-44.

Caspi, A., Moffitt, T. E., Cannon, M., McClay, J., Murray, R., Harrington, H., ... Craig, I. W. (2005). Moderation of the effect of adolescent-onset cannabis use on adult psychosis by a functional polymorphism in the catechol-0-methyltransferase gene: longitudinal evidence of a gene $X$ environment interaction. Biological Psychiatry, 57, 11171127.
Codony, M., Alonso, J., Almansa, J., Vilagut, G., Domingo-Salvany, A., Pinto-Meza, A.,... Haro, J. M. (2007). Utilización de los servicios de salud mental en la población general española. Resultados del estudio ESEMeD-España. Actas Españolas de Psiquiatria, 35, 21-28.

De Irala, J., Ruiz-Canela, M., y Martinez-Gonzalez, M. A. (2005). Causal relationship between cannabis use and psychotic symptoms or depression. Should we wait and see? A public health perspective. Medical Science Monitor, 11, RA355-RA358.

Degenhardt, L., Dierker, L., Chiu, W. T., Medina-Mora, M. E., Neumark, Y., Sampson, N.,... Kessler, R. C. (2010). Evaluating the drug use "gateway" theory using cross-national data: consistency and associations of the order of initiation of drug use among participants in the WHO World Mental Health Surveys. Drug and Alcohol Dependence, 108, 84-97.

Degenhardt, L., Hall, W., \& Lynskey, M. (2003). Exploring the association between cannabis use and depression. Addiction, 98, 1493-1504.

Delegación del Gobierno para el Plan Nacional sobre Drogas y Ministerio de Sanidad y Consumo (2006). Cannabis II. Informes de la comisión clínica. Madrid: Ministerio de Sanidad y Política Social.

Gonzalvo, B., Barral, C., Grau-López, L., Esteve, O., y Roncero, C. (2012). Comorbilidad psiquiátrica en adolescentes consumidores de cannabis. Trastornos Adictivos, 13, 109-112.

Grant, B. F. \& Pickering, R. (1998). The relationship between cannabis use and DSM-IV cannabis abuse and dependence: results from the National Longitudinal Alcohol Epidemiologic Survey. Journal of Substance Abuse Treatment, 10, 255-264.

Grant, B. F., Stinson, F. S., Dawson, D. A., Chou, S. P., \& Ruan, W. J. (2005). Co-occurrence of DSM-IV personality disorders in the United States: results from the National Epidemiologic Survey on Alcohol and Related Conditions. Comprehensive Psychiatry, 46, 1-5.

Grella, C. E., Hser, Y. I., Joshi, V., \& Rounds-Bryant, J. (2001). Drug treatment outcomes for adolescents with comorbid mental and substance use disorders. Journal of Nervous and Mental Disease, 189, 384-392.

Guillem, E., Pelissolo, A., Vorspan, F., Bouchez-Arbabzadeh, S., y Lépine, J. P. (2009). Facteurs sociodémographiques, conduites addictives et comorbidité psychiatrique des usagers de cannabis vus en consultation spécialisée. L'Encéphale, 35, 226-233.

Haro, J. M., Alonso, J., Pinto-Meza, A., Vilagut Saiz, G., Fernández, F., Codony, M.,...Autonell, J. (2008). The Epidemiology of Mental Disorders in the General Population of Spain. Chapter 19. Part II. Country-Specific Chapters. In e.Ronald C.Kessler y T.Bedirhan Üstün (Eds.), The WHO World Mental Health Surveys: global Perspectives on the Epidemiology of Mental Disorders. (pp. 406-430). New York: Cambridge University Press.

Hasin, D. S., Trautman, K. D., Miele, G. M., Samet, S., Smith, M., \& Endicott, J. (1996). Psychiatric Research Interview for Substance and Mental Disorders (PRISM): reliability for substance abusers. American Journal of Psychiatry, 153, 1195-1201.

Herrero, M. J., Domingo-Salvany, A., Torrens, M., Brugal, M. T., \& the ITINERE Investigators. (2008). Psychiatric comorbidity in young cocaine users: induced versus independent disorders. Addiction, 103, 284-293. 
Lee, S., Tsang, A., Breslau, J., Aguilar-Gaxiola, S., Angermeyer, M., Borges, G.,... Kessler, R. C. (2009). Mental disorders and termination of education in high-income and low- and middle-income countries: epidemiological study. British Journal of Psychiatry, 194, 411-417.

Lynskey, M. \& Hall W (2000). The effects of adolescent cannabis use on educational attainment: a review. Addiction, 95, 1621-1630.

Macleod, J. \& Hickman, M. (2010). How ideology shapes the evidence and the policy: what do we know about cannabis use and what should we do? Addiction, 105, 1326-1330.

Martin-Santos, R., Torrens, M., Poudevida, S., Langohr, K., Cuyas, E., Pacifici, R.,... de la Torre, R. (2009). 5-HTTLPR polymorphism, mood disorders and MDMA use in a 3-year follow-up study. Addiction biology, 15, 15-22.

Miller, P. G. \& Sonderlund, A. L. (2010). Using the internet to research hidden populations of illicit drug users: a review. Addiction, 105, 1557-1567.

Moore, T. H., Zammit, S., Lingford-Hughes, A., Barnes, T. R., Jones, P. B., Burke, M. \& Lewis, G. (2007). Cannabis use and risk of psychotic or affective mental health outcomes: a systematic review. The Lancet, 370, 319-328.

National Survey on Drug Use and Health. (2008). Substance Abuse and Mental Health Services Administration, Office of Applied Studies. Results from the 2007 National Survey on Drug Use and Health: National Findings (NSDUH Series H-34, DHHS Publication No.SMA08-4343). Rockville, MD. Retrived from http://oas.samhsa. gov/nsduh/2k7nsduh/2k7results.cfm.

Nocon, A., Berge, D., Astals, M., Martin-Santos, R., \& Torrens, M. (2007). Dual diagnosis in an inpatient drug-abuse detoxification unit. European Addiction Research, 13, 192-200.

Observatorio Español de Drogas (2009). Informe 2009. Situación y tendencias de los problemas de drogas en España. Madrid: Ministerio de Sanidad y Política Social.

Observatorio Europeo de las Drogas y las Toxicomanías. (2011). Informe anual 2010. El problema de la drogodependencia en Europa. Luxemburgo: Oficina de Publicaciones de la Unión Europea.

Observatorio Europeo de las Drogas y Toxicomanias (2009). Informe Anual 2009. El problema de la drogodependencia en Europa. Luxemburgo: Oficina de Publicaciones de la Unión Europea.

Palmer, R. H., Young, S. E., Hopfer, C. J., Corley, R. P., Stallings, M. C., Crowley, T. J.,...Hewitt, J. K. (2009). Developmental epidemiology of drug use and abuse in adolescence and young adulthood: Evidence of generalized risk. Drug and Alcohol Dependence, 102, 78-87.

Rodriguez-Llera, M. C., Domingo-Salvany, A., Brugal, M. T., Silva, T. C., Sanchez-Niubo, A., \& Torrens, M. (2006). Psychiatric comorbidity in young heroin users. Drug and Alcohol Dependence, 84, 48-55.

Roncero, C., Daigre, C., Gonzalvo, B., Valero, S., Castells, X., Grau-Lopez, L.,... Casas, M. (2011). Risk factors for cocaine-induced psychosis in cocaine-dependent patients. European psychiatry: the journal of the Association of European Psychiatrists. doi.org/10.1016/j. bbr.2011.03.031

Rounsaville, B. J., Kranzler, H. R., Ball, S., Tennen, H., Poling, J., \& Triffleman, E. (1998). Personality disorders in substance abusers: relation to substance use. Journal of Nervous and Mental Disease, 186, 87-95.
Skinner, R., Conlon, L., Gibbons, D., \& McDonald, C. (2011). Cannabis use and non-clinical dimensions of psychosis in university students presenting to primary care. Acta Psychiatrica Scandinavica, 123, 21-27.

Solowij N, Stephens RS, \& Roffman RA (2002). Cognitive functioning of long-term heavy cannabis users seeking treatment. Journal of the American Medical Association, 287, 1123-1131.

Stinson, F. S., Ruan, W. J., Pickering, R., \& Grant, B. F. (2006). Cannabis use disorders in the USA: prevalence, correlates and co-morbidity. Psychological Medicine, 36, 1447-1460.

Szerman, N., Arias, F., Vega, P., Babin, F., Mesías, B., Basurte, I.,... Poyo Calvo, F. (2011). Pilot study on the prevalence of dual pathology in community mental health and substance misuse services in Madrid. Adicciones, 23, 249-255.

Tims, F. M., Dennis, M. L., Hamilton, N., Buchan, J., Diamond, G., Funk, R. \& Brantley, L. B. (2002). Characteristics and problems of 600 adolescent cannabis abusers in outpatient treatment. Addiction, 97 Supp/ 1, 46-57.

Torrens, M., Serrano, D., Astals, M., Perez-Dominguez, G., \& MartinSantos, R. (2004). Diagnosing comorbid psychiatric disorders in substance abusers: validity of the Spanish versions of the Psychiatric Research Interview for Substance and Mental Disorders and the Structured Clinical Interview for DSM-IV. American Journal of Psychiatry, 161, 1231-1237.

Veen, N. D., Selten, J. P., van, d. T., I, Feller, W. G., Hoek, H. W., \& Kahn, R. S. (2004). Cannabis use and age at onset of schizophrenia. American Journal of Psychiatry, 161, 501-506.

Weiner, M. D., Sussman, S., McCuller, W. J., \& Lichtman, K. (1999). Factors in marijuana cessation among high-risk youth. Journal of Drug Education, 29, 337-357.

Winstock, A. R., Ford, C., \& Witton, J. (2010). Assessment and management of cannabis use disorders in primary care. British Medical Journal, 340, c1571. 
